\title{
Ordovician polychaeturid polychaetes: Taxonomy, distribution and palaeoecology
}

Olle Hints and Mats E. Eriksson

Acta Palaeontologica Polonica 55 (2), 2010: 309-320 doi: http://dx.doi.org/10.4202/app.2009.0086

The fossil polychaete family Polychaeturidae is considered as monogeneric and comprises four species of the genus Pteropelta. Pteropelta, originally established on isolated scolecodonts (the carriers), is revised and the apparatus-based Polychaetura is shown to be a junior synonym of Pteropelta. In addition to Pteropelta gladiata and Pteropelta kielanae, Pteropelta huberti sp. nov., and Pteropelta sp. A are herein described from the Upper Ordovician of Estonia and Sweden. Polychaeturids include some of the most common and characteristic scolecodont-bearing polychaetes in the Ordovician of Baltoscandia. They first appeared in the early Darriwilian (Mid Ordovician), flourished in the Late Ordovician and disappeared in the early Silurian. The distribution patterns of individual polychaeturid species infer regional biostratigraphical potential. Polychaeturids were geographically widespread during the Ordovician and have been recorded from at least three palaeocontinents.

Key words: Annelida, Polychaeta, scolecodonts, polychaete jaws, taxonomy, distribution, Ordovician, Baltica.

Olle Hints [ㅇlle.Hints@ gi.ee], Institute of Geology at Tallinn University of Technology, Ehitajate 5, 19086 Tallinn, Estonia; Mats E. Eriksson [Mats.Eriksson@geol.lu.se], Department of Geology, GeoBiosphere Science Centre, Lund University, Sölvegatan 12, SE-223 62 Lund, Sweden.

This is an open-access article distributed under the terms of the Creative Commons Attribution License (for details please see creativecommons.org), which permits unrestricted use, distribution, and reproduction in any medium, provided the original author and source are credited. 
FoF 